\title{
Małgorzata Żbikowska*
}

\section{GLOSA DO POSTANOWIENIA SĄDU NAJWYŻSZEGO Z 30 WRZEŚNIA 2015 ROKU, SYGN. I KZP 8/15 ${ }^{1}$}

\section{Streszczenie}

Zaprezentowana glosa opisuje problematykę reprezentacji oraz wykonywania praw małoletniego pokrzywdzonego przez jednego z jego rodziców w sytuacji, gdy drugi z nich jest osobą podejrzaną o popełnienie przestępstwa przeciwko małoletniemu. Wskazane zagadnienie zostało rozstrzygnięte przez Sąd Najwyższy w postanowieniu z 30 września 2015 roku (I KZP 8/15). Autorka w całości podziela konkluzję Sądu Najwyższego, także dochodząc do przekonania, iż małoletni nie może być reprezentowany w postępowaniu karnym (również w postępowaniu przygotowawczym toczącym się in rem) przez żadnego z rodziców w sytuacji, gdy jeden z nich uzyskał w postępowaniu przygotowawczym status osoby podejrzanej.

Słowa kluczowe: pokrzywdzony, małoletni, reprezentacja małoletniego, kurator, osoba podejrzana

Do Sądu Najwyższego zostało skierowane na podstawie przepisu art. 441 k.p.k. zagadnienie prawne - w przekonaniu kierującego je Sądu Rejonowego wymagające zasadniczej wykładni ustawy - o następującej treści:

* dr Małgorzata Żbikowska, Katedra Postępowania Karnego Wydziału Prawa i Administracji Uniwersytetu Szczecińskiego; adres e-mail: malgorzata.zbikowska@wpiaus.pl

1 Biul. SN 2015, nr 12. 
Czy regulacje zawarte w art. 51 § 2 k.p.k., art. $306 \S 1$ k.p.k. i w art. 98 $\S 2$ pkt 2 kodeksu rodzinnego i opiekuńczego wyłączają uprawnienia rodzica małoletnich pokrzywdzonych do wykonywania ich praw w toku postępowania przygotowawczego w sprawie, w której osobą podejrzaną o popełnienie przestępstwa na szkodę małoletnich jest drugi z rodziców?

Wskazane pytanie prawne Sądu Rejonowego wyłoniło się na tle następującej sytuacji procesowej. Rodzice małoletnich pokrzywdzonych ${ }^{2}$ rozwiedli się. Władzę rodzicielską powierzono matce, zaś ojcu małoletnich zapewniono prawo do współdecydowania o istotnych kwestiach związanych z małoletnimi oraz ustalono sposób i terminy kontaktowania się z nimi i zabierania ich poza miejsce zamieszkania.

Matka małoletnich pokrzywdzonych zawiadomiła prokuraturę o możliwości popełnienia czynu zabronionego polegającego na ,nadużyciach seksualnych wobec małoletnich dzieci”. Na skutek złożonego do właściwych organów procesowych zawiadomienia o popełnieniu przestępstwa wszczęto postępowanie przygotowawcze w formie dochodzenia, które następnie umorzono wobec braku danych uzasadniających podejrzenie popełnienia czynu zabronionego (zob. art. $17 \S 1$ pkt 1 k.p.k.). Na rzeczone postanowienie o umorzeniu dochodzenia $\mathrm{w}$ fazie in rem pełnomocnik matki małoletnich pokrzywdzonych wniósł w ich imieniu zażalenie, zaskarżając je w całości oraz wnosząc o jego uchylenie. Sąd Rejonowy, uprawniony do rozpoznania zażalenia, powziął wątpliwość co do tego, czy matka małoletnich pokrzywdzonych może (jest uprawniona) wykonywać ich prawa, w tym wnosić środki zaskarżenia w postępowaniu przygotowawczym toczącym się w sprawie (in rem), w którym osobą podejrzaną jest ojciec małoletnich pokrzywdzonych. „Pytający Sąd zauważył, że w świetle orzecznictwa Sądu Najwyższego rodzic małoletniego nie może, działając w charakterze przedstawiciela ustawowego, wykonywać praw tego małoletniego jako pokrzywdzonego w postępowaniu karnym, jeżeli oskarżonym jest drugi z rodziców (uchwała Sadu Najwyższego z 30 września 2010 roku, I KZP 10/10, OSNKW 2010, z. 10, poz. 84).

2 Posługiwanie się w niniejszym szkicu pojęciem pokrzywdzonego jest pewnym skrótem myślowym. Precyzyjnie ujmując, przed uprawomocnieniem się wyroku mamy do czynienia $z$ hipotetycznie pokrzywdzonym ( $w$ ujęciu procesowym). W ujęciu faktycznym pokrzywdzonym jest bowiem osoba fizyczna lub prawna, której dobro prawne zostało bezpośrednio naruszone lub zagrożone przez przestępstwo (art. 49 § 1 k.p.k.). Fakt naruszenia lub zagrożenia dobra prawnego może zostać jednak potwierdzony wyłącznie przez sąd w prawomocnym wyroku. Więcej w przedmiocie definicji pokrzywdzonego zob. R. Kmiecik, Ustawowa definicja pokrzywdzonego (uwagi na tle art. 40 k.p.k.), „Annales UMCS” Sectio G 1977, vol. 24, nr 9, s. 165 i n. 
Wskazał jednak, że brak jest podobnej jasności w przypadku postępowania przygotowawczego prowadzonego $\mathrm{w}$ fazie in rem, w której formalnie brak podejrzanego, zwłaszcza w przypadkach gdy - jak w niniejszej sprawie - treść zawiadomienia o przestępstwie jednoznacznie wskazuje drugiego rodzica jako osobę podejrzaną". Sąd Najwyższy zasadnie - na tle zaprezentowanego stanu faktycznego - odmówił podjęcia uchwały z powodu niespełnienia wszystkich przesłanek określonych w przepisie art. 441 k.p.k. W uzasadnieniu postanowienia o odmowie podjęcia uchwały w gruncie rzeczy zawarł odpowiedź na postawione pytanie prawne. Abstrahując od przytaczania przywołanych przez Sąd Najwyższy (słusznych) powodów odmowy podjęcia uchwały w przedmiocie skierowanego doń zagadnienia prawnego ${ }^{3}$, należy w tym miejscu skoncentrować się na merytorycznej odpowiedzi na skierowane do SN zagadnienie prawne. Podjęta analiza w gruncie rzeczy wymaga odwołania się do interpretacji wybranych przepisów kodeksu rodzinnego i opiekuńczego ${ }^{4}$, zaprezentowana zaś w przywołanym postanowieniu konkluzja wyrażona przez Sąd Najwyższy została w tym miejscu w całości zaaprobowana.

Aby rozstrzygnąć wskazane powyżej zagadnienie prawne, w rezultacie nie trzeba, na co wskazał już SN, odwoływać się do szczegółowej interpretacji przepisu art. $51 \S 2$ k.p.k., zgodnie z którym, jeżeli pokrzywdzonym jest małoletni albo ubezwłasnowolniony całkowicie lub częściowo, prawa jego wykonuje przedstawiciel ustawowy albo osoba, pod której pieczą pokrzywdzony pozostaje 5 . Kwestia przedstawicielstwa ustawowego i reprezentacji małoletniego nie musi się zawsze pokrywać, choć przedstawiciel ustawowy najczęściej posiada jednocześnie uprawnienia do reprezentowania małoletniego. Żeby odpowiedzieć na to pytanie prawne, nie trzeba także podejmować szczegółowej interpretacji przepisu art. $306 \S 1$ k.p.k., który stanowi o zaskarżalności postanowienia o odmowie wsz-

3 Należy wskazać, że zgodnie z przepisem art. 441 § 1 k.p.k., jeżeli przy rozpoznawaniu środka odwoławczego wyłoni się zagadnienie prawne wymagające zasadniczej wykładni ustawy, sąd odwoławczy może odroczyć rozpoznanie sprawy i przekazać zagadnienie do rozstrzygnięcia Sądowi Najwyższemu. Spośród przesłanek, które uzasadniają wydanie przez Sąd Najwyższy uchwały, znajduje się konieczność uznania, że dane - a poddane rozstrzygnięciu - zagadnienie wymaga zasadniczej wykładni ustawy. Na tle zaprezentowanego stanu faktycznego, jak (słusznie) stwierdził SN, nie doszło do zrealizowania tej przesłanki. Wskazana wątpliwość mogła bowiem zostać samodzielnie rozstrzygnięta na skutek podjęcia przez Sąd Rejonowy właściwych zabiegów interpretacyjnych, dających odpowiedź na rzeczone pytanie prawne.

4 Ustawa z 25 lutego 1964 r. - Kodeks rodzinny i opiekuńczy (Dz. U. z 1964 r., nr 9, poz. 59).

5 Więcej w tym przedmiocie zob. W. Hazuka, Wykonywanie praw pokrzywdzonego matoletniego, gdy sprawca przestepstwa jest jego przedstawiciel ustawowy lub opiekun, „Problemy Praworządności” 1972, nr 10, s. 34-42. 
częcia postępowania przygotowawczego ${ }^{6}$. Kluczem do poprawnej odpowiedzi na postawione pytanie jest więc analiza treści przepisu art. $98 \S 2$ pkt 2 i $\S 3$ oraz art. 99 kodeksu rodzinnego i opiekuńczego (k.r.o.) na tle postępowania karnego, a ściślej postępowania przygotowawczego prowadzonego w fazie in rem. Otóż, zgodnie z dyspozycją przepisu art. 98 k.r.o. rodzice są przedstawicielami ustawowymi dziecka pozostającego pod ich władzą rodzicielską. Jeżeli dziecko pozostaje pod władzą rodzicielską obojga rodziców, każde z nich może działać samodzielnie jako przedstawiciel ustawowy dziecka (§1). Jednakże żadne z rodziców nie może reprezentować dziecka: 1) przy czynnościach prawnych między dziećmi pozostającymi pod ich władzą rodzicielską, 2) przy czynnościach prawnych między dzieckiem a jednym z rodziców lub jego małżonkiem, chyba że czynność prawna polega na bezpłatnym przysporzeniu na rzecz dziecka albo że dotyczy należnych dziecku od drugiego z rodziców środków utrzymania i wychowania $(\S 2)^{7}$.

6 Na marginesie należy zaznaczyć, iż Sąd Najwyższy trafnie dostrzegł i jasno to wyraził w przytoczonym już postanowieniu, że na tle zaprezentowanego stanu faktycznego nie chodziło o treść przepisu art. $306 \S 1$ k.p.k., stanowiącego o zaskarżalności postanowienia o odmowie wszczęcia postępowania przygotowawczego, ale o przepis art. 306 § 1a k.p.k., stanowiący o zaskarżalności postanowienia o umorzeniu postępowania przygotowawczego. Wszak na tle zaistniałego w sprawie stanu faktycznego doszło przecież do umorzenia dochodzenia, a nie do odmowy jego wszczęcia. Jednakże niezależnie od powyższego błędnego wskazania przez Sąd Rejonowy podstawy prawnej, dla rozstrzygnięcia podniesionego tu zagadnienia nie jest konieczna, ani nawet zasadna szczegółowa analiza przepisu art. 306 § 1a k.p.k.

7 W sytuacji, w której żaden z rodziców nie może reprezentować małoletniego - co zostanie jeszcze podkreślone - na mocy przepisu art. 99 k.r.o. zostaje powołany kurator przez sąd opiekuńczy. Zasady ustanowienia kuratora przewidziane są w kodeksie rodzinnym i opiekuńczym (zob. art. 178 i n. k.r.o.). Na marginesie można tylko zwrócić uwagę na pewną niezmiernie istotną kwestię związaną z powołaniem osoby kuratora w sytuacji, w której żaden z rodziców nie może reprezentować dziecka z powodu uwikłania w proces karny jednego z rodziców. Wskazana, a zasługująca na szczególne uwzględnienie kwestia, była przedmiotem rozważań Trybunału Konstytucyjnego, zamieszczonych w postanowieniu z 11 lutego 2014 r., S 2/14, OTK Seria A 2014, nr 2, poz. 19. We wskazanym postanowieniu TK zwracał uwagę, iż instytucja kurateli - z perspektywy interesów i praw dziecka - występującego w postępowaniu karnym w charakterze pokrzywdzonego - odgrywa niezmiernie istotną rolę oraz że ,tylko wprowadzenie kuratora, jako obiektywnego reprezentanta dziecka w postępowaniu karnym, minimalizuje niebezpieczeństwo konfliktu pomiędzy interesem jednego z rodziców, chcącego reprezentować dziecko w procesie toczącym się przeciwko drugiemu z rodziców, a interesem dziecka”. Jednakże, jak wskazał TK, przepisy kodeksu rodzinnego i opiekuńczego nie przewidują żadnych szczególnych wymagań wobec osób, które mają uzyskać legitymację do wystąpienia w procesie karnym w charakterze kuratora. W konsekwencji kuratorem osoby małoletniej pokrzywdzonej mogą być nawet osoby nieprzeszkolone w pracy z małoletnimi, a (co gorsza) nawet nieznające się dostatecznie na prawie (tytułem przykładu warto zwrócić uwagę na przywołany przez Trybunał Konstytucyjny przykład reprezentowania w procesie karnym małoletniego przez pracownika sekretariatu sądu). Powyższe sytuacje mogą realnie zagrażać interesom procesowym małoletniego pokrzywdzonego w procesie karnym, a w konsekwencji nie mogą być aprobowane. Na marginesie należy także zwrócić uwagę na kwestię przebiegu procesu karnego 
Na tle zaprezentowanego stanu faktycznego małoletni pokrzywdzeni pozostawali pod władzą rodzicielską tylko jednego z rodziców - ich matki. Co do zasady, matka pokrzywdzonych jako osoba sprawująca władzę rodzicielską jest-zgodnie z przepisem art. $98 \S 1$ k.r.o. - przedstawicielem ustawowym małoletnich. Z kolei przedstawiciel ustawowy małoletnich w postępowaniu karnym reprezentuje ich, a zatem także wykonuje ich prawa, w tym m.in. prawo do wnoszenia środków zaskarżenia na wszelkie decyzje procesowe posiadające przymiot zaskarżalności, w tym na tzw. negatywne postanowienia wydawane w postępowaniu przygotowawczym (postanowienia o odmowie wszczęcia i o umorzeniu postępowania przygotowawczego). Prawo do reprezentowania małoletniego w postępowaniu karnym przez jego przedstawiciela ustawowego wynika już z treści przytoczonego przepisu art. 51 § 2 k.p.k. Jednakże wskazana sytuacja, związana z zasadami reprezentacji dziecka, ulega skomplikowaniu w sytuacji, w której to jeden z rodziców małoletniego jest osobą podejrzaną w postępowaniu karnym. Uzyskanie statusu osoby podejrzanej (a zatem nie podejrzanego) w postępowaniu karnym intuicyjnie winno zrodzić pytanie o zasady reprezentacji małoletniego oraz o ewentualną modyfikację zasad ogólnych dotyczących reprezentacji dziecka, a wyrażonych w kodeksie rodzinnym i opiekuńczym. Ewentualna intuicyjna odpowiedź winna jednak znaleźć wyraźne odzwierciedlenie w przepisach prawa. Zgodnie z przepisem art. $98 \S 3$ k.r.o. przepisy paragrafu poprzedzającego (a zatem paragrafu stanowiącego o tym, że w określonych sytuacjach żadne z rodziców nie może reprezentować dziecka) stosuje się odpowiednio w postępowaniu przed sądem lub innym organem państwowym. Na tle niniejszego przepisu prawnego, zarówno w orzecznictwie sądowym ${ }^{8}$, jak i w literaturze ${ }^{9}$, wypracowano niekwestionowany

(skuteczności czynności karnoprocesowych) w przypadku braku obligatoryjnego poinformowania przez sąd opiekuńczy ustanowionego kuratora o prawie do przystąpienia $\mathrm{w}$ imieniu małoletniego do sprawy w charakterze oskarżyciela posiłkowego (a w konsekwencji późniejszej niemożności np. wnoszenia środków zaskarżenia) lub na kwestę zaniechania przez właściwy organ procesowy złożenia wniosku do sądu opiekuńczego o ustanowienie kuratora dla małoletniego, skutkującego np. brakiem możliwości wstąpienia do postępowania w charakterze oskarżyciela posiłkowego. Szczegółowa analiza tych przypadków - z perspektywy naruszenia normy prawnej zdekodowanej z treści przepisu art. 16 k.p.k. - przekracza jednak ramy tego opracowania. Zob. także wyrok TK z 21 stycznia 2014 r. (SK 5/12).

8 Zob. np. uchwała SN (7) z 30.09.2010 r., I KZP 10/10, OSNKW 2010, nr 10, poz. 84; postanowienie SN - Izba Karna z 11 stycznia 2011 r., V KK 125/10, Legalis nr 509923.

9 Zob. np. W. Sych, Glosa do uchwały Sądu Najwyższego z dnia 30 września 2010 r., sygn. I KZP 10/10, „Ius Novum” 2011, nr 1, s. 197-203. K. Gromek, Kodeks rodzinny i opiekuńczy. Komentarz, Warszawa 2013, s. 567; J. Mierzwińska-Lorencka, Karnoprawna ochrona dziecka przed wykorzystywaniem seksualnym, Warszawa 2012, s. 112 i n.; J. Misztal-Konecka, Reprezenta- 
pogląd o tym, że żaden z rodziców nie może reprezentować małoletniego w sytuacji, gdy jeden z nich jest podejrzanym (art. $71 \S 1$ k.p.k.) lub oskarżonym (art. $71 \S 2$ k.p.k.) w postępowaniu karnym. Implikacją przyjęcia takiego założenia jest konieczność skorzystania przez sąd z regulacji prawnej - art. 99 k.r.o. Z kolei zgodnie z tym przepisem prawnym, jeżeli żadne z rodziców nie może reprezentować dziecka pozostającego pod władzą rodzicielską, reprezentuje je kurator ustanowiony przez sąd opiekuńczy ${ }^{10}$.

Jak wskazano, niekwestionowany pogląd na temat wyłączenia możliwości reprezentowania małoletniego przez każdego z rodziców dotyczy sytuacji, gdy jeden $\mathrm{z}$ nich jest podejrzanym lub oskarżonym w postępowaniu karnym. Słowem, w postępowaniu przygotowawczym - zgodnie z treścią zaprezentowanego poglądu - wyłączenie reprezentacji rodziców małoletniego ma miejsce w sytuacji, gdy wobec jednego z rodziców wydano już postanowienie o przedstawieniu zarzutów (art. 313 k.p.k.), albo której bez wydania takiego postanowienia przedstawiono zarzut $\mathrm{w}$ związku $\mathrm{z}$ przystąpieniem do przesłuchania $\mathrm{w}$ charakterze podejrzanego (art. $308 \S 2$ k.p.k., art. $325 \mathrm{~g} \S 2$ k.p.k.) (zob. art. $71 \S 1$ k.p.k.). Ergo, powołanie kuratora uprawnionego do reprezentowania spraw małoletniego pokrzywdzonego jest konsekwencją - w świetle tego poglądu - przejścia postępowania przygotowawczego $\mathrm{z}$ fazy in rem $\mathrm{w}$ fazę in personam (a zatem prowadzenia postępowania przeciwko konkretnej osobie wskazanej w postanowieniu o przedstawieniu zarzutów lub w protokole przesłuchania osoby podejrzanej w charakterze podejrzanego). Jednakże zaprezentowany stan faktyczny, będący przedmiotem rozstrzygnięcia Sądu Najwyższego, a także analizy podjętej w niniejszym szkicu, nie dotyczył sytuacji, w której jeden z rodziców uzyskał status podejrzanego

cja w postępowaniu karnym pokrzywdzonego małoletniego lub ubezwłasnowolnionego, „Monitor Prawniczy” 2009, nr 16, s. 868. J. Misztal-Konecka niefortunnie jednak argumentowała: „Z uwagi zatem na sprzeczność interesów wykluczone jest wykonywanie praw pokrzywdzonego małoletniego lub ubezwłasnowolnionego zarówno przez przedstawiciela ustawowego będącego sprawcą przestępstwa, jak też przez drugiego z przedstawicieli ustawowych niebędącego sprawcą przestępstwa. Rodzic (opiekun) niebędący sprawcą przestępstwa powinien zwrócić się do sądu opiekuńczego o ustanowienie kuratora". Autorka niezasadnie posługiwała się pojęciem sprawcy czynu zabronionego, albowiem na etapie ustanawiania kuratora dla osoby małoletniej nie można jeszcze przesądzić, że drugi z rodziców jest sprawcą czynu zabronionego. Zasadniej zatem było posługiwać się pojęciem osoby podejrzanej, podejrzanego lub oskarżonego.

10 W sytuacjach wskazanych w przepisie art. 98 § 2 i 3 k.r.o. sąd rozpoznający sprawę (lub inny organ) jest zobowiązany zwrócić się do sądu opiekuńczego o ustanowienie dla strony niemającej zdolności procesowej kuratora. Zob. orzeczenie SN z 4 października 1966 r., II CZ 117/66, OSNCP 1967, nr 2, poz. 40. Z kolei powinno ustanowić się tylu kuratorów, ile dzieci ma być reprezentowanych. H. Ciepła, w: Kodeks rodzinny i opiekuńczy. Komentarz, red. K. Piasecki, Warszawa 2011, s. 755. 
w postępowaniu przygotowawczym, ale sytuacji, w której postępowanie przygotowawcze zostało zakończone (umorzone) jeszcze w fazie in rem. Co za tym idzie, postępowanie przygotowawcze w omówionym przypadku prowadzono i zakończono (umorzono) w sprawie, w której nikomu (w tym również żadnemu z rodziców małoletniego) nie przedstawiono zarzutu popełnienia przestępstwa, chociaż na etapie prowadzonego postępowania przygotowawczego ojciec małoletnich pokrzywdzonych uznawany był za osobę podejrzaną (jednoznacznie wynikało to także z zawiadomienia o popełnieniu przestępstwa). Podniesione tu zagadnienie, a związane z pytaniem, czy wyłączone jest wykonywanie praw dziecka przez oboje rodziców w sytuacji, gdy jedno z nich jest osobą podejrzaną o popełnienie przestępstwa na szkodę małoletniego, nie było szerzej podejmowane w literaturze przedmiotu. Także i Sąd Najwyższy - przed wydaniem tytułowego postanowienia - nie podejmował szerszych rozważań w tym zakresie (najprawdopodobniej więc Sądy Rejonowe - zasadnie - same rozstrzygały w tym przedmiocie, podejmując stosowne decyzje procesowe w sytuacji zetknięcia się $\mathrm{z}$ analogicznymi sytuacjami faktycznymi). Na tle kodeksu postępowania karnego status osoby podejrzanej niewątpliwie różni się od statusu podejrzanego ${ }^{11}$. Ten ostatni bowiem jest stroną postępowania przygotowawczego (zob. art. 299 § 1 k.p.k.), a w związku z tym ma wiele uprawnień procesowych i obowiązków procesowych o stosunkowo szerszym zakresie, aniżeli uprawnienia procesowe i obowiązki procesowe osoby podejrzanej. Całkowicie uzasadniona pozostaje zatem sytuacja, w której żadne $\mathrm{z}$ rodziców nie może reprezentować dziecka, gdy jedno $\mathrm{z}$ nich jest podejrzane ${ }^{12}$ o popełnienie czynu zabronionego wobec małoletniego. Niewątpliwie wówczas interesy małoletniego mogą nie być należycie reprezentowane z powodu konfliktu (sprzeczności interesów, choćby hipotetycznej ${ }^{13}$ ) jego rodziców czy sprzeczności interesów dziecka $\mathrm{z}$ interesem rodziców ${ }^{14}$. Mogłoby to dotyczyć zarówno sytuacji

11 W przedmiocie statusu osoby podejrzanej w postępowaniu karnym zob. np. A. Tęcza-Paciorek, Pojęcie osoby podejrzanej i jej uprawnienia, „Prokuratura i Prawo” 2011, nr 11, s. 56-75; R. Kmiecik, Prawo do milczenia zatrzymanej osoby podejrzanej (w świetle reguły nemo tenetur), „Prokuratura i Prawo” 2000, nr 7-8, s. 17-22; J. Skorupka, Zatrzymanie procesowe osoby podejrzanej, „Prokuratura i Prawo” 2007, nr 11, s. 16-32.

12 A zatem posiada status podejrzanego.

13 Na hipotetyczność sprzeczności interesów dziecka z interesami jego rodziców zwracał już uwagę Sąd Najwyższy w opisywanym w niniejszym szkicu postanowieniu.

14 Na taką sprzeczność interesów zwracał już uwagę R.A. Stefański, w: Przegląd uchwat Izby Karnej Sądu Najwyższego w zakresie prawa karnego procesowego za 2003 r., ,Wojskowy Przegląd Prawniczy" 2004, nr 2, s. 103. Zob. także: J. Misztal-Konecka, Pojednanie w prawie karnym (zagadnienia wybrane), „Prokuratura i Prawo” 2013, nr 12, s. 68. 
- jak wskazał Sąd Najwyższy - w której przedstawiciel ustawowy małoletniego niebędący podejrzanym podejmuje pewne czynności procesowe w jego imieniu, jak i sytuacji, w której nie podejmuje żadnych czynności procesowych, szkodząc tym samym interesom małoletniego ${ }^{15}$. Z tych wszystkich względów jedynym podmiotem obiektywnie działającym w interesie małoletniego może być kurator wyznaczony przez sąd opiekuńczy.

Analiza powyżej zakreślonego problemu, dotyczącego wyłączenia możliwości reprezentowania małoletniego przez oboje rodziców w sytuacji, gdy jeden z nich jest osobą podejrzaną o popełnienie przestępstwa na szkodę małoletniego, powinna rozpocząc się od wykładni językowej stosownych przepisów kodeksu rodzinnego i opiekuńczego, albowiem to właśnie ten akt prawny rozstrzyga o tym, kiedy żaden z rodziców nie może reprezentować dziecka przy czynnościach prawnych między dzieckiem a jednym z rodziców (odwołanie do § 2 pkt 2 art. 98 k.r.o.), a także przy czynnościach prawnych w postępowaniu przed sądem lub innym organem państwowym (art. $98 \S 3$ k.r.o.). Owym innym organem państwowym może być niewątpliwie prokurator lub inny organ prowadzący postępowanie przygotowawcze. Przytoczony przepis prawny - art. $98 \S 3$ k.r.o. stanowi jedynie o postępowaniu przed sądem lub innym organem państwowym, słusznie nie dookreślając jednak dokładnego etapu takiego postępowania. Innymi słowy, kwestia ewentualnego przedstawienia zarzutów konkretnej osobie nie ma wpływu na kwestię ustalenia niemożności reprezentowania w postępowaniu karnym małoletniego, ponieważ z wykładni językowej przepisu art. $98 \S 3$ k.r.o. wyraźnie wynika, że żaden z rodziców małoletniego nie może go reprezentować, gdy w toczącym się postępowaniu karnym jedno z rodziców miałoby dokonać czynności procesowej w imieniu małoletniego, ale przeciwko drugiemu z rodziców $^{16}$. Za powyższym założeniem przemawia także odpowiednie stosowanie

15 Wyłączenie reprezentacji małoletniego przez oboje jego rodziców, w sytuacji, o której mowa w przepisie art. 98 § 2 k.r.o., a także w sytuacji, o której mowa w przepisie art. $98 \S 3$ k.r.o. w zw. z art. $98 \S 2$ k.r.o. ma miejsce bez względu na to, czy pomiędzy rodzicami małoletniego zachodzi sprzeczność interesów. Jak wskazała H. Ciepła: „Przepis ten (art. 98 § 2 k.r.o. - M.Ż.) ma zastosowanie bez względu na to, czy władzę rodzicielską sprawują oboje rodzice, czy też jedno z nich. Redakcja przepisu, w przeciwieństwie do art. 22 prawa rodzinnego z 1946 r., który posługiwał się pojęciem «sprzeczności interesów» wskazuje, że w wymienionych wypadkach rodzice nie mogą reprezentować dziecka, chociażby nawet żadna sprzeczność interesów nie występowała”. H. Ciepła, Kodeks..., s. 753.

16 Podobnie wywodził W. Hazuka, pisząc, że użyte w przepisie art. $98 \S 2$ k.r.o. pojęcie czynności prawnej odnosi się zarówno do czynności cywilnoprawnych, jak i do czynności karnoprocesowych. W konsekwencji Autor uznał, że istnieje konieczność wyłączenia reprezentowania dziecka przez jednego rodzica w sytuacji, gdy drugi z nich popełnił przestępstwo na szkodę 
przepisu art. $98 \S 2$ pkt 2 k.r.o. w postępowaniu karnym, na co wyraźnie zezwala przepis art. $98 \S 3$ k.r.o. W tym wypadku odpowiednie stosowanie oznaczać będzie dostosowanie przepisu art. $98 \S 2$ pkt 2 k.r.o. do specyfiki czynności karnoprocesowych, a ściślej - na tle zaprezentowanego stanu faktycznego - do czynności przeprowadzanych w postępowaniu przygotowawczym. Ergo, w postępowaniu karnym - na przygotowawczym etapie, na którym nie doszło jeszcze do przedstawienia zarzutów - nie tyle chodzi o niedopuszczalną reprezentację dziecka przy czynności prawnej między dzieckiem a jednym z rodziców, ale o niedopuszczalną reprezentację dziecka przy dokonywaniu przez jednego rodzica czynności karnoprocesowej w imieniu dziecka, a przeciwko drugiemu z rodziców (w tym wypadku chodzi zatem o faktyczną bądź hipotetyczną sprzeczność interesów). Odpowiednie stosowanie przepisów prawa cywilnego (rodzinnego i opiekuńczego) w postępowaniu karnym w tym wypadku oznacza więc przystosowanie rzeczonych przepisów prawnych do założonych realiów karnoprocesowych.

Zaprezentowana powyżej wykładnia językowa przepisu art. $98 \S 3$ k.r.o. zostaje także poparta wykładnią funkcjonalną ${ }^{17}$. Niewątpliwie celem przepisu art. 98 k.r.o. jest ochrona interesów prawnych i faktycznych małoletniego, tak w postępowaniu cywilnym, jak i w postępowaniu karnym. Ochrona polega na tym, że ewentualna sprzeczność interesów dziecka i interesów jednego z rodziców lub sprzeczność pomiędzy interesami rodziców małoletniego nie może mieć wpływu na interesy procesowe małoletniego, które powinny być objęte obiektywną i realną, a nie fikcyjną ochroną. Sytuacja, w której osobą podejrzaną o popełnienie czynu zabronionego przeciwko małoletniemu jest jeden $\mathrm{z}$ jego rodziców, niewątpliwie pozostaje zbliżona - z perspektywy interesów małoletniego i sytuacji faktycznej - do takiego stanu, w którym jeden z rodziców małoletniego uzyskał już status podejrzanego w postępowaniu przygotowawczym. Na ustalenie ratio legis przepisu art. 98 k.r.o. nie ma wpływu stan zaawansowania postępowania przygotowawczego oraz ewentualne przedstawienie zarzutów osobie podejrzanej, ale faktyczne interesy małoletniego pokrzywdzonego. Należy uznać, iż bez wątpienia faktyczne interesy małoletniego mogą być realnie zagro-

małoletniego. Autor z tego zakresu wyłączył jedno przestępstwo - niealimentacji (art. 209 k.k.), albowiem jest ono związane z dochodzeniem środków utrzymania i wychowania. Zob. W. Hazuka, Wykonywanie praw pokrzywdzonego..., s. 38 i n.

17 Należy także zwrócić uwagę, iż za taką wykładnią przemawiają także względy aksjologiczne, odwołujące się do wartości. Na tle zaprezentowanego stanu faktycznego wartością tą będzie dobro dziecka. Tylko obiektywna reprezentacja dziecka przez podmiot niezaangażowany w spór (kurator) może w należyty sposób zapewnić dobro małoletniego. 
żone, gdy jego reprezentacja miałaby zostać powierzona jednemu z rodziców, który podejmuje czynności procesowe wobec drugiego z rodziców posiadającego status osoby podejrzanej o popełnienie przestępstwa na szkodę małoletniego. Do takiej czynności jednego rodzica wobec drugiego z nich z pewnością można zaliczyć wniesienie zażalenia na postanowienie o umorzeniu postępowania przygotowawczego w fazie in rem, gdy osobą podejrzaną o popełnienie czynu zabronionego przeciwko małoletniemu był drugi z jego rodziców. Wykładnia funkcjonalna wskazanego powyżej przepisu prawnego pozwala zatem na przedkładanie argumentów nie tylko w sferze prawnej, ale także w zakresie celu tego przepisu prawnego, odnoszącego się także do sfery faktycznej (celem tego przepisu prawnego jest bowiem realne zapewnienie ochrony interesów prawnych i faktycznych małoletniego).

Z tych wszystkich względów w całości należy podzielić wniosek Sądu Najwyższego, że: „(...) zarówno litera przepisów art. 98 § 2 pkt 2 i $\S 3$ k.r.o., jak i ich ratio legis prowadzą do wniosku, że stosowanie zakazu reprezentacji małoletnich pokrzywdzonych przez ich rodzica jest uzasadnione nie tylko w tych postępowaniach karnych, w których drugi rodzic jest oskarżonym, ale także na etapie in rem, w którym drugi rodzic jest osobą podejrzaną o popełnienie przestępstwa na szkodę małoletnich dzieci”. Zaprezentowana wykładnia wskazanych przepisów prawnych kodeksu rodzinnego i opiekuńczego wydaje się bowiem najtrafniejsza prakseologicznie.

\section{GLOSS TO THE RESOLUTION OF THE SUPREME COURT OF 30 SEPTEM- BER 2015 - FILE REF. NO. I KZP 8/2015}

This gloss describes the problems related to the reprezentation of a minor victim, when one of his parents is a person suspected of committing a crime against a minor. This issue was resolved by the Supreme Court in its decision of 30 September 2015 (I KZP 8/2015). The author agrees with the Supreme Court also thinking that a minor can not be represented in criminal proceedings by any of the parents, when one of them is a suspect.

Keywords: victim, minor, reprezentative of a minor, curator, a person suspected 